\title{
The Influence of Learning Role-Playing Model Toward Competence of Writing Financial Report at Vocational High School
}

\author{
Maraden Junias Arnoldus*; Susilaningsih Susilaningsih; Djoko Santoso; \\ Sebelas Maret University, Indonesia \\ Email: maraden.arnoldus@gmail.com
}

http://dx.doi.org/10.18415/ijmmu.v5i4.220

\begin{abstract}
This article discusses about influence of learning model of role-playing toward the competence of writing financial report. This article was wrotten by using the quantitative research method with the experimental design of one-group of pretest and posttest. This research was done by giving pretest in the beginning of the lesson to know the beginning competence of the students. The test of hypothesis was done by using Z test with SPSS IBM 22. Based on the beginning calculation, it could be found that $p$ value (Sig) $<\alpha, 0.000<0.05$ meant that $\mathrm{H} 0$ was rejected. Thus, $\mathrm{H} 1$ was stated that the score of posttest was better than the score of pretest. It meant that the learning model of role-playing affected the competence in writing the financial report.
\end{abstract}

Keywords: Learning Model; Role-playing Model; Financial Report;

\section{Introduction}

The improvement of acceptance from professional and international Accounting toward the Accounting graduates who have particular generic skill has caused Accounting teachers to reflect the learning model which fulfill the requirements (Ballantine \& Larres., 2007). The learning process also faced changes from the teacher center in which the teacher as an information agent to the students center in which the students should be more active in the learning process. Those changes affect the learning process done by the current teachers. Those changes consisting of the atmosphere of the balance, transparant, tolerant, and not being arrogant should be achieved because those aspects are important in which the teachers are the leaders who accommodate various questions and the students' needs (Aunurrahman., 2012).

The development process of the students' potential and skills at the middle school is more dominant at vocational schools: Vocational High School and Madrasah Aliyah Kejuruan. The graduates of Vocational High School can continue their educational level to the higher level. They are expected to have jobs based on their interest and major. Based on the explanation, the learning process at vocational high school does not only focus on the cognitive competence, but also on the affective and psycomotor competence. The needed learning is that the learning which can develop cognitive and socio-emotional competence because the job field cannot be separated from social interaction. Besides, it is also necessary 
to have the learning which can describe the real interaction happened so that the graduates of vocational high school, especially in Accounting, are expected to be able to work well because they have experiences during the learning process. Thus, it is necessary to create the classroom atmosphere to develop the students' competence through their own experiences. This kind of process needs constructivistics learning.

Based on the explanation above, vocational high school has the program of Accounting skill which can prepare the students to have the competence in their interest and major. The use of appropriate model can cause the interesting learning process, the acceptable materials, and the alive atmosphere of the classroom so that the students can have experiences in their vocational fields. Moreover, the bad teaching model of the teacher can affect the students' learning outcomes. Thus, when the teacher lectures, the students will get bored, sleepy, passive, and only write notes (Slameto., 2010). The used model has to support the achievement of the objectives of Accounting subject and focus more on the skills. The applied model has to be able to improve the students' participation in Accounting learning so that the students are more interested and active in joining the learning process. The development of the students' cognitivity can be done so that the understanding of Accounting subject can be better. The students do not only develop their cognitive competence, but also their interaction competence toward their friends and teachers.

The expecting learning is that the learning can develop the students' knowledge based on their experiences and social interaction. In the learning process, it is expected to have relationship between teachers to students and students to students. The appropriate learning theory is constructivism theory. Constructivism is a philosophy of knowledge focusing on knowledge is construction (Von Glasersfeld in Bettencourt., 1989). This theory stated that the students' thoughts can be developed based on their own experiences. The teacher has to give freedom to the students to investigate, observe, and solve their own problems (Slameto., 2010). Thus, in the learning process, the students are given the chance to be more active in the learning process. This case can help to shape the students' thoughts in understanding the materials that the teacher gives. With the interaction in the learning process, the students will get many experiences and new knowledge getting from other people.

The learning model following the constructivism theory is a cooperative learning model. Jolliffe (2007) stated that the essential of cooperative learning needs the students to be able to work together in small groups and support each other to improve their own learning and others' learning. It means that cooperative learning is the same as group learning. Cooperative learning is a practical method used to improve the motivation and improvement in the classroom. Learning in groups can improve the students' confidence, communication skill, and active participation in the learning process (Chu., 2014). The learning model of role-playing is an appropriate model to support the learning process at vocational high school. The learning model of role-playing focuses more on the skills in which this model is the most appropriate model because the learning process at vocational high school focuses more on the skills. Role-playing is a learning model taking the context of the real life and putting on the learning process. This condition makes the students ready to face the job field.

\section{Methodology}

This research was done at one of the vocational high schools in Kupang City, East Nusa Tenggara, Indonesia, especially at Class X Accounting. This research was an experimental research. The used design was pre-experimental designs consisting of one group pretest-posttest design. The population of this research was the students of Class X Accounting consisting of two classes containing 65 students. All of the students were the samples of this research. The methods used in this research to collect the data were documentation and test (multiple choice). 
Based on the result of the instrument test, from 30 questions of the test, it was known that there were five invalid questions. Based on the calculation of SPSS by using Gutman Split-Half Coefficient, it was gotten 0.858 which meant that the research instrument was in high category and could be used to do the measurement. Based on the calculation by using 2010 Microsoft Excel in getting the levels of the questions' difficulties, there were 8 questions for the difficult level and 17 questions for the medium level, while there were 7 questions for the good level and 18 questions for the good enough level.

The technique of analyzing the data in this research was $\mathrm{Z}$ test. $\mathrm{Z}$ test will be used if the research is a population research. $\mathrm{Z}$ test can be done if it fulfills the prerequisites of the analysis. The prerequisite test is a normality to be used to know whether the samples of the research come from the normal population or not. Tests of data normality were Lilliefors test and homogeneity test. They were used to know whether the samples came from the homogeneity population or not. The data gotten in the research would be analyzed by using hypothesis test. The procedure of hypothesis test used $\mathrm{Z}$ test supported by software of IBM SPSS 22.

\section{Result}

1. Result of the Analysis Prerequisite Test

a. Normality Test

Table 1 Normality test

\begin{tabular}{ccccccc}
\hline & \multicolumn{3}{c}{ Kolmogorov-Smirnov $^{\mathrm{a}}$} & \multicolumn{3}{c}{ Shapiro-Wilk } \\
\cline { 2 - 7 } & Statistic & $\mathrm{df}$ & Sig. & Statistic & df & Sig. \\
\hline Pretest Score & .112 & 32 & $.200^{*}$ & .929 & 32 & .038 \\
Posttest Score & .186 & 32 & .006 & .919 & 32 & .019 \\
\hline
\end{tabular}

*. This is a lower bound of the true significance.

a. Lilliefors Significance Correction

Based on Table 1, it can be seen that the significant scores of the pretest and posttest at Class Accounting 1 were bigger than the score of $\alpha$ (alpha), $0.200>0.05$. This case meant that the scores of pretest and posttest at Class Accounting 1 came from normal population.

b. Homogeneity

Homogeneity test is used to test the similarity of variance or the homogeneity of each population. A variant is homogeneity when p-value (Sig.) $>\alpha$. The result of homogeneity test can be seen in Table 2 .

Table 2 Result of variance homogeneity test

\begin{tabular}{cccc}
\hline Levene Statistic & df1 & df2 & Sig. \\
\hline, 889 & 4 & 24 &, 485 \\
\hline
\end{tabular}

Table 2 can shows that p-value (Sig.) $>\alpha, 0.525>0.05$ which meant that the scores of roleplaying class had the similarity of variance.

2. Result of Hypothesis Test 


\section{a. Z Test of Role-Playing Class}

The second test was done to answer the second hypothesis whether there was an influence of using lesson model of role-playing towards the competence of writing financial report or not. There were some stages in this test:

\section{1) Doing Prerequisite Test}

Before doing $\mathrm{Z}$ test, normality and homogeneity test were done. Based on the prerequisite test, it could be known that the data were normal and homogeneous.

2) Determining Hypothesis

$\mathrm{H}_{0}: \mu \leq 38,79$ (Posttest score was not much better than pretest score)

$\mathrm{H}_{1} \quad: \mu>38,79$ (Posttest score was much better than pretest score)

\section{3) Defining Significance Level}

The significance level was $\alpha=5 \%$ or $\alpha=0,05$.

4) Doing the Test

Table 3 Result of hypotesis test of one sample of role-playing class

\begin{tabular}{|c|c|c|c|c|c|c|}
\hline & \multicolumn{6}{|c|}{ Test Value $=57.50$} \\
\hline & \multirow[b]{2}{*}{$\mathrm{T}$} & \multirow[b]{2}{*}{ Df } & \multirow[b]{2}{*}{ Sig. (2-tailed) } & \multirow{2}{*}{$\begin{array}{l}\text { Mean } \\
\text { Difference }\end{array}$} & \multicolumn{2}{|c|}{$\begin{array}{l}95 \% \text { Confidence Interval of } \\
\text { the Difference }\end{array}$} \\
\hline & & & & & Lower & Upper \\
\hline Role-plaving & 4.668 & 31 & .000 & 7.75000 & 4.3641 & 11.1359 \\
\hline
\end{tabular}

5) Decision and Conclusion of the Test

The decision of the test will reject $\mathrm{H}_{0}$ if $\mathrm{Z}_{\text {count }}>\mathrm{Z}_{\text {table }}$ or $p$-Value (Sig.) $<\alpha$ and accept $\mathrm{H}_{0}$ if $\mathrm{Z}_{\text {count }}$ $<\mathrm{Z}_{\text {table }}$ or $p$-Value (Sig.) $>\alpha$. Based on the table 4.10 , p-value $(\mathrm{Sig})<\alpha$ was $0,000<0,05$ which meant it rejected $\mathrm{H}_{0}$. Thus, hypotesis stated posttest score was much better than pretest score was accepted.

Based on the calculation of SPSS, it can be concluded that the lesson model of role-playing had a big influence towards the competence of writing financial report.

\section{Discussion}

A vocational high school focuses more on the skill process because the graduates of vocational high schools are expected to be able to work after graduating. Based on that case, the learning process in vocational high schools has to focus more on the skills. Creating skills in the learning process can be done 
by giving experiences during the teaching and learning process. Based on the explanation, SMK N 6 Kupang has to be able to prepare the graduates focusing more on the skills during the teaching and learning process.

Based on the observation, the atmosphere in the classroom changes when the learning process has been more than 90 minutes. That change can be the students' low attention or concentration causing the students cannot understand the materials given. Besides, the students' learning interest can decrease causing a lot of students do other activities so that they cannot focus on the materials. Subini, et al. (2012) and Ahmadi \& Supriyono (2013) stated that school time can influence the students' learning process. The learning process in the afternoon cannot be much better than in the morning because the students feel tired and the neighborhood is more crowded. The students' fatigue is the most common cause of saturation causing the boredom (Syah., 2013). If the students join the learning process with the inappropriate condition, they will have difficulties in understanding the materials. Those difficulties happen because the students cannot concentrate and think well (Daryanto., 2009).

In addition to the teacher-centered learning and explanations that are still too general, the materials provided by the teacher are not enough to foster the attention and interests of the students. Slameto (2010) stated that to make the students study well, the materials should be able to attract the students' interest. Besides, the materials should be based on the students' interest because those kind of materials will motivate the students to study more (Syah., 2013). It is because the teacher expects the students to understand the materials well. Slameto (2010) contended that that kind of condition cannot happen because the mastery of the materials should be based on the students' capabilities. This condition causes the students' reactions to expect more that the teacher can explain the materials in details so that the understanding of the materials can be accepted easily. Thus, the most important thing is that the defined objectives can be achieved.

Based on the observation, one of the strategies to solve the problem is by using the appropriate learning model. Constructivism learning model is an appropriate learning model. One of the learning models in cooperative learning is learning model of role-playing. Role-playing is a designed condition where the students can assume the characters or identities to achieve the learning objectives (Barkley., Cross., \& Major., 2012). Silberman \& Auerbach (2013) stated that role-playing is a major focus in the active training behavior because it is the most popular strategy to help the students to understand the materials and practice the specific skills. Hamdani (2011) contended that role-playing is a mastery of learning materials through developing the students' imagination and understanding by playing it as an alive or a dead character.

After observing and determining the learning model of role-playing, the researcher applied the learning model. The students were given pretest before applying the learning model to know their beginning capabilities. Based on the calculation of the pretest, the lowest score was 10 (0), the highest score was 100, and the average score was 57.50. The average score was not achieved in KKBM (70). It meant that the score of the students' beginning capabilities was still low. After given pretest, the students was explained about the general materials. The material in this research was about the competence of writing financial report at the service companies made based on the basic equation of accounting. The teacher does not only explain about the materials, but also explains about the used learning model.

After explaining, the teacher gives instructions to the students to create groups. The groups can be 5 groups and have 6 until 7 members. Every group is instructed as if it is a service company. Those five groups consist of the business focusing on travel, convection printing, salon, machine shop, and photocopy. Every group has a name. The next stage is by applying the learning model of role-playing in the learning process. 
Before applying the learning model, the students did some practices. The practices were by doing some transactions based on the instructions on applying the learning model. The type and number of transactions depended on the group. After doing some practices, the teacher gave the opportunities for the students to ask about the learning process. The next stage was that the students played again the arranged transaction on the instructions on applying the learning model of role-playing. Every member of the group did transactions to another group. In role-playing, the students used their own experiences to play the real life context (Kucharčíková., Durišová., \& Tokarčíková., 2015: 2493). Every member of the group who did transactions wrote them in their journal. Similarly with the group being addressed by other group members, the group should also record the transactions that occurred. By doing role-playing, the students can develop their knowledge, skills, and attitude effectively because it is a pedagogy technique in roleplaying (Sogunro., 2004: 370).

After each transaction was done, the students was instructed to create the basic equation of accounting based on the journal that had been made. Then, the students created the financial report based on basic equation of accounting in the form of balance sheet report, loss/profit statement, and report of change of capital. By applying the learning model of role-playing, the students had experiences in how to create a financial report. Kettula \& Berghall (2013: 568) stated that role-playing is an experience. The experience gives the students opportunities to apply the theories and practice the skills. Role-playing is also a valuable tool to promote social lesson. Because of that, the learning model is used as practice and lesson to pay more attention on management and planning (Salvini., van Paassen., Ligtenberg., Carrero., \& Bregt., 2016: 119-120).

Then, the teacher discussed with the students about the learning process. The discuss was about an evaluation towards the roles of every group. Every group gave suggestions for another group so that there would be reciprocal relationship in the future. In addition, the teacher gave opportunities to the students to ask about the materials. Then, the teacher reexplained the materials. After discussing, the teacher gave posttest to the students to know whether the students could understand the materials or not after applying the learning model of role-playing. Based on the finding, the students' capabilities had been improved from 57.50 to 65.25 . However, the finding showed that the average score after applying the leraning model of role-playing had not achieved the score of KKBM.

Based on the first finding, the students did not respond well towards the applied learning lesson. The students still could not understand well the stages of the applied learning model. Success depends on the students' intention to be more active. Some students perhaps play openly by threatening or embarrassing (Kucharčíková., Ďurišová., \& Tokarčíková., 2015: 2493). It happened because the students accepted new things so that they still needed to adapt. In the next meeting, the students were more active than in the previous meeting. The students could be more communicative than in the first meeting. There was also reciprocal relationship of every group. It can happen because from methodology objectives, roleplaying can make individuals to be more active in participating and getting experiences (Gourmelon, Chlous-Ducharme., Kerbitiou., Rouan., \& Bioret., 2013: 106). Role-playing also stimulates reciprocal collaboration and encourages competition between opposite sides (Zdravkova., 2014: 73). In playing role, the students use their own experiences to play the real life context (Kucharčíková, Durišová, \& Tokarčíková., 2015: 2493). It could be shown when doing transactions, for example, on transactions conducted to groups that had a travel business, the students determined the route of travel on the local area.

Because this was an experimental research, it was necessary to have test by using statistics. The tested hypothesis was "there was an influence of using the learning model of role-playing towards the competence of writing financial report." The hypothesis test was done by using Z test and SPSS. The used statistical hypothesis was H0: posttest score was not much better than pretest score in role-playing class and H1: posttest score was much better than pretest score in role-playing class. Based on the statistical 
calculation by using IBM SPSS Statistics 22 , the result was p-value (Sig.) $<\alpha, 0.00<0.05$. Thus, the hypothesis stated that getting posttest score much better than pretest score in jigsaw class was accepted. This case showed that there was an influence of using the learning model of jigsaw towards the competence of writing financial report.

The finding was appropriate with Hamdani (2018: 30) who showed that role-playing had a positive influence towards the students' understanding. Role-playing is a learning activity which gets substantial support as an enjoyable and influencial practice so that it can be used to have interactive discussion to explore the identified learning concept during the teaching and learning process (Pepper \& Clements., 2008: 23). Role-playing is a source of experience to have self-reflection so that the students can create their own confidence, success, and motivation.

\section{Conclusion}

The learning model of role-playing had a significant influence towards the competence of writing financial report. The influence could be gotten based on the comparison between posttest score or the gotten score after applying the learning model of role-playing and pretest score or the gotten score before applying the learning model of role-playing. The result of the test by using one sample of $\mathrm{Z}$ test supported by SPSS showed that the gotten significant score was $p$-value (Sig.) $<\alpha, 0.00<0.05$. Thus, $\mathrm{H}_{1}$ stated that getting posttest score much better than pretest score in role-playing class was accepted. It showed that the learning model of role-playing had an influence towards the competence of writing financial report because posttest score was significantly better than pretest score.

\section{References}

Ahmadi, H. A \& Supriyono, W. (2013). Psikologi Belajar. Jakarta: Rineka Cipta.

Aunurrahman. (2012). Belajar dan Pembelajaran. Bandung: Alfabeta.

Ballantine, J. \& Larres, P. M. (2007). Cooperative Learning: A Pedagogy to Improve Students' Generic Skills?. Education + Training, 49: 126-137.

Barkley, E. E., Cross, K. P., \& Major, C. H. (2012). Collaborative Learning Tecniques: Teknik-Teknik Pembelajaran Kolaboratif. Terj. N. Yusron. Bandung: Nusa Media.

Bettencourt, A. (1989). Wat is Constructivism and Why Are They All Talking About It? Michigan State University.

Chu, S.Y. (2014). Application of the Jigsaw Cooperative Learning Method in Economics Course. International Journal of Managerial Studies and Research (IJMSR), 2: 166-172.

Dahar, R. W. (2011). Teori-Teori Belajar \& Pembelajaran. Jakarta: Penerbit Erlangga.

Darsono, \& Ashari. (2005). Pedoman Praktis Memahami Laporan Keuangan. Yogyakarta: CV. Andi Soffet.

Daryanto. (2009). Panduan Proses Pembelajaran Kreatif \& Inovatif: Teori \& Praktik dalam Pengembangan Profesionalisme bagi Guru. Jakarta: AV Publisher. 
Gourmelon, F., Chlous-Ducharme, F., Kerbitiou, C., Rouan, M., \& Bioret, F. (2013). Role-playing Game Developed From A Modelling Process: A Relevant Participatory Tool For Sustainable Development? A Co-Construction Experiment In An Insular Biosphere Reserve. Land Use Policy, 32: 96-107.

Hamdani, M. R. (2018). Learning How to Be Transformational Leader Trough A Skill-Building, RolePlay Exercise. International Journal Of Management Education, 16: 26-36.

Hamdani. (2011). Strategi Belajar Mengajar. Bandung: CV Pustka Setia.

Jolliffe, W. (2007). Cooperative Learning in the Classroom. Puting It Into Practice. London: SAGE.

Kartikahadi, H., Sinaga, R. U., Syamsul, M., \& Siregar, S. V. (2012). Akuntansi Keuangan berdasarkan SAK berbasis IFRS. Jakarta: Salemba Empat.

Kettula, K. \& Berghäll, S. (2013). Drama-Based Role-Play: A Tool To Supplement Work-Based Learning In Higher Education. Journal of Workplace Learning, 25: 556-575.

Kucharčíková, A., Ďurišová, M., \& Tokarčíková, E. (2015). The role plays implementation in teaching macroeconomics. Procedia-Social and Behavioral Sciences, 174: 2489-2496.

Pepper, M. P. \& Clements, M. D. 2008. Extended Scenario Role- Playing: Cumulative Learning For Supply Chain Participants. Development and Learning in Organizations: An International Journal. 22: 21-24.

Salvini, G., van Paassen, A., Ligtenberg, A., Carrero, G. C., \& Bregt, A. K. (2016). A Role-playing Game as A Tool to Facilitate Social Learning and Collective Action Towards Climate Smart Agriculture: Lessons Learned From Apuí, Brazil. Environmental Science \& Policy. 63: 113-121.

Sardiman, A. M. (2012). Interaksi dan Motivasi: Belajar-Mengajar. Jakarta: Rajawali Pers.

Silberman, M. \& Auebach, C. (2013). Active Training: Pedoman Preaktis Tentang Teknik, Desain, Contoh Kasus, dan Kiat. Terj. M Khozim. Bandung: Penerbit Nusa Media.

Slameto. (2010). Belajar dan Faktor-Faktor yang Mempengaruhinya. Jakarta: Rineka Cipta.

Sogunro, O. A. (2004). Efficacy of Role- Playing Pedagogy in Training Leaders: Some Reflections. Journal of Management Development. 23: 355-371.

Subini, N, dkk. (2012). Psikologi Pembelajaran. Yogyakarta: Mentari Pustaka.

Syah, M. (2013). Psikologi Belajar. Jakarta: PT Raja Grafindo Persada.

Zdravkova, K. (2014). Learning Computer Ethics And Social Responsibility With Tabletop Role-playing Games. Journal of Information, Communication and Ethics In Society. 12: 60-75. 


\section{Copyrights}

Copyright for this article is retained by the author(s), with first publication rights granted to the journal.

This is an open-access article distributed under the terms and conditions of the Creative Commons Attribution license (http://creativecommons.org/licenses/by/4.0/). 